\title{
Spring water chemistry in a formerly glaciated area of western Poland: the contribution of natural and anthropogenic factors
}

\author{
Anna Szczucińska ${ }^{1}$
}

Received: 29 May 2015/ Accepted: 8 March 2016/Published online: 13 April 2016

(c) The Author(s) 2016. This article is published with open access at Springerlink.com

\begin{abstract}
To assess natural and anthropogenic impacts on spring water chemistry, seasonal and spatial hydrochemical changes in 20 springs were studied in the western part of Poland. Spring water was sampled every 3 months from November 2011 to October 2013. The analyses investigated major cation, anion, and trace element concentrations. Moreover, water temperature, electrical conductivity, and $\mathrm{pH}$ were measured in the field. For five springs, isotopic analyses of nitrates were conducted. The results revealed that the water composition was similar for most of the elements studied. However, in the case of $\mathrm{Fe}, \mathrm{Mn}^{2+}$, $\mathrm{Pb}^{2+}$, and nitrates, spatial and seasonal variations were relatively significant. The concentrations of total iron and manganese were found to exceed the Polish legal limits for drinking water in 70 and $85 \%$ of the springs, respectively. In addition, $\mathrm{Pb}^{2+}$ levels were found to be highly variable; in some periods, the concentration was 10 times higher than the limit for drinking water. In some springs, elevated nitrate concentrations were found with a maximum of 74-mg $\mathrm{NO}_{3}{ }^{-} / \mathrm{L}$, which is also in excess of the legal limit. The seasonally high levels of total $\mathrm{Fe}$ and $\mathrm{Mn}^{2+}$ are considered to be related to natural geo- and hydrochemical changes, but the high concentrations of $\mathrm{Pb}^{2+}$ and nitrates suggest anthropogenic pollution. The nitrates originate from agricultural practices, whereas $\mathrm{Pb}^{2+}$ may come from
\end{abstract}

Electronic supplementary material The online version of this article (doi:10.1007/s12665-016-5548-y) contains supplementary material, which is available to authorized users.

Anna Szczucińska

szana@amu.edu.pl

1 Institute of Physical Geography and Environmental Planning, Adam Mickiewicz University, Dzięgielowa 27, 61-680 Poznań, Poland several sources. Hydrochemical monitoring must, therefore, consider seasonal variations, because the water properties may not permit its use during some periods, i.e., for drinking purposes.

Keywords Groundwater monitoring $\cdot$ Springs $\cdot$ Trace elements $\cdot$ Nitrate $\cdot$ Poland

\section{Introduction}

Groundwater chemistry and the origins of its constituents are widely discussed in the literature (e.g., Appelo and Postma 1993; Kehew 2001; Xing et al. 2013). In particular, studies have discussed the issue of groundwater in the active exchange zone (Kazakis and Vaudouris 2015; Dragon and Górski 2015). This is the zone in which groundwater is affected by both natural and anthropogenic processes. The influence of anthropogenic factors is of particular importance here. These factors can cause deterioration in the quality of shallow groundwater (Moosavirad et al. 2013; Amiri et al. 2015). Infiltration of shallow groundwater can further pollute deeper aquifers. Groundwater quality is important, because the poor surface water quality in Poland makes it impossible to use it as a drinking water source (Buszewski and Kowalkowski 2003). Thus, groundwater is the main source of drinking water for the population. In Poland, it accounts for approximately $70 \%$ of the water intended for human consumption. This percentage is even higher in lowland areas embraced by Pleistocene glaciations. Here, groundwater aquifers, formed mainly in Quaternary deposits, usually composed of sands and sands with gravels, are essential for water usage, as they contribute over $90 \%$ of water for human consumption. Most of the aquifers are not isolated from the 
ground surface by an impermeable layer; as a result, groundwater is heavily exposed to the infiltration of contaminants from the surface. The main threat to this water is uncontrolled discharge of untreated municipal and domestic sewage as well as uncontrolled landfills. This problem is also partly related to the lack of sewage systems, especially in rural areas. In the Lubuska Upland area, only $75 \%$ of the rural population has a sewer system (Szablowska et al. 2013). However, agricultural contamination of groundwater, which is often underestimated, should also be considered (Jeong 2001; Naseems et al. 2010; Abdesselam et al. 2013; Rottray 2015). In such conditions, it is necessary to have a reliable system to monitor groundwater quality. In the Lubuska Upland area, the density of monitoring points for shallow groundwater is low, and they are located to the north and south of the study area. These are not permanent monitoring points, and the water quality is assessed based on annual or biannual sampling throughout the year. Therefore, due to the lack of fixed monitoring points in the area, the springs may be appropriate for testing the groundwater quality. Moreover, the primary aim of the Water Framework Directive, in relation to groundwater, is the supply of high-quality water and, hence, to preserve and improve its chemical status. Therefore, a critical aspect is to study changes in groundwater quality to inform the population about potential hazards. This is particularly important in rural areas, where more monitoring points are required to best examine the impact of agricultural activities.

Groundwater outflows (springs) are relatively simple to monitor. Their physicochemical properties reflect natural processes occurring in the underground environment as well as those caused by human activities. It is believed that groundwater has a relatively constant chemical composition. However, a previous pilot study conducted in one of the Lubuska Upland catchments - the Gryżynka catchment (Szczucińska et al. 2010)—showed that the concentrations of some trace elements in spring water may show seasonal variability. Periodically, these elements (e.g., $\mathrm{Pb}^{2+}$ ) reach values exceeding acceptable standards for drinking water. On the basis of those results, the present research was undertaken to investigate the seasonal variability of the spring water composition at a regional scale. Thus, various types of springs were selected, including those derived from subsurface aquifer levels (unconfined aquifers) and those from deeper levels (inter-glacial till aquifers) covered by layers of sediment of low permeability (confined aquifers).

The aim of this study is to assess whether the seasonal variations in the chemical composition of spring water, especially parameters related to anthropogenic impact, are common in the lowland regions composed of sediments deposited by the Pleistocene glaciations. Because groundwater from Quaternary aquifers is the main water source for the population in this region, it is crucial to establish if groundwater contamination is occurring seasonally, especially with biogenic compounds and trace elements that are health hazards for the local population. Moreover, the research intends to determine whether the assessment of human impact on the chemical state of the groundwater of a region by sampling water twice per year, in accordance with the recommendations of the Minister of the Environment's Regulation on Groundwater Monitoring, is sufficient.

\section{Study area}

The study area is the Lubuska Upland, which is located in the western part of Poland (Fig. 1). It occupies approximately $5200 \mathrm{~km}^{2}$. This area was entirely covered by an ice sheet during the last Pleistocene glaciation. Its geological structure (Fig. 2) is dominated by glacial tills separated by glaciofluvial deposits of varying thickness, from a few to more than $150 \mathrm{~m}$. The glaciofluvial sands and gravels, as well as river deposits, serve as the major groundwater aquifers used for drinking and industrial purposes. The rate of groundwater recharge depends on the amount of precipitation, the degree of isolation from the surface, the aquifer thickness, and the water circulation systems. The aquifers near the surface are unconfined, and those sandwiched between older glacial till deposits form at least two confined aquifers. The unconfined groundwater layer is associated with sand and gravel deposits of the latest Vistula glaciation, and occurs in ice-marginal valleys, river valleys, and the outwash plain. The highest values of the effective infiltration (reaching $20 \mathrm{~m}^{3} / \mathrm{h} / \mathrm{km}^{2}$ ) are observed within the Pliszka outwash plain (Qs) (Fig. 3). Hence, this aquifer is used locally as the public water supply. The confined intertill aquifers are associated with sand and gravel layers separated by the glacial tills of older glaciations. The upper intertill aquifer is characterized by lower values of effective infiltration from 6 to $9 \mathrm{~m}^{3} / \mathrm{hkm}^{2}$, and is rarely used for the public water supply. The lower intertill aquifer, with a thickness ranging from 5 to $60 \mathrm{~m}$, is characterized by a filtration coefficient of $31-84 \mathrm{~m} /$ day, and is widely used for the public water supply in the Lubuska Upland area. In most of the area, this aquifer is characterized by subartesian pressure. Its main recharge area is located on the Lubuska Upland plateau, with drainage to the rivers surrounding Lubuska Upland and their smaller tributaries supplied by the studied springs.

Because most of the area is composed of surface sediments with relatively high infiltration coefficients, the uppermost groundwater level is highly susceptible to the infiltration of contaminants (Brzóska et al. 1998). The 


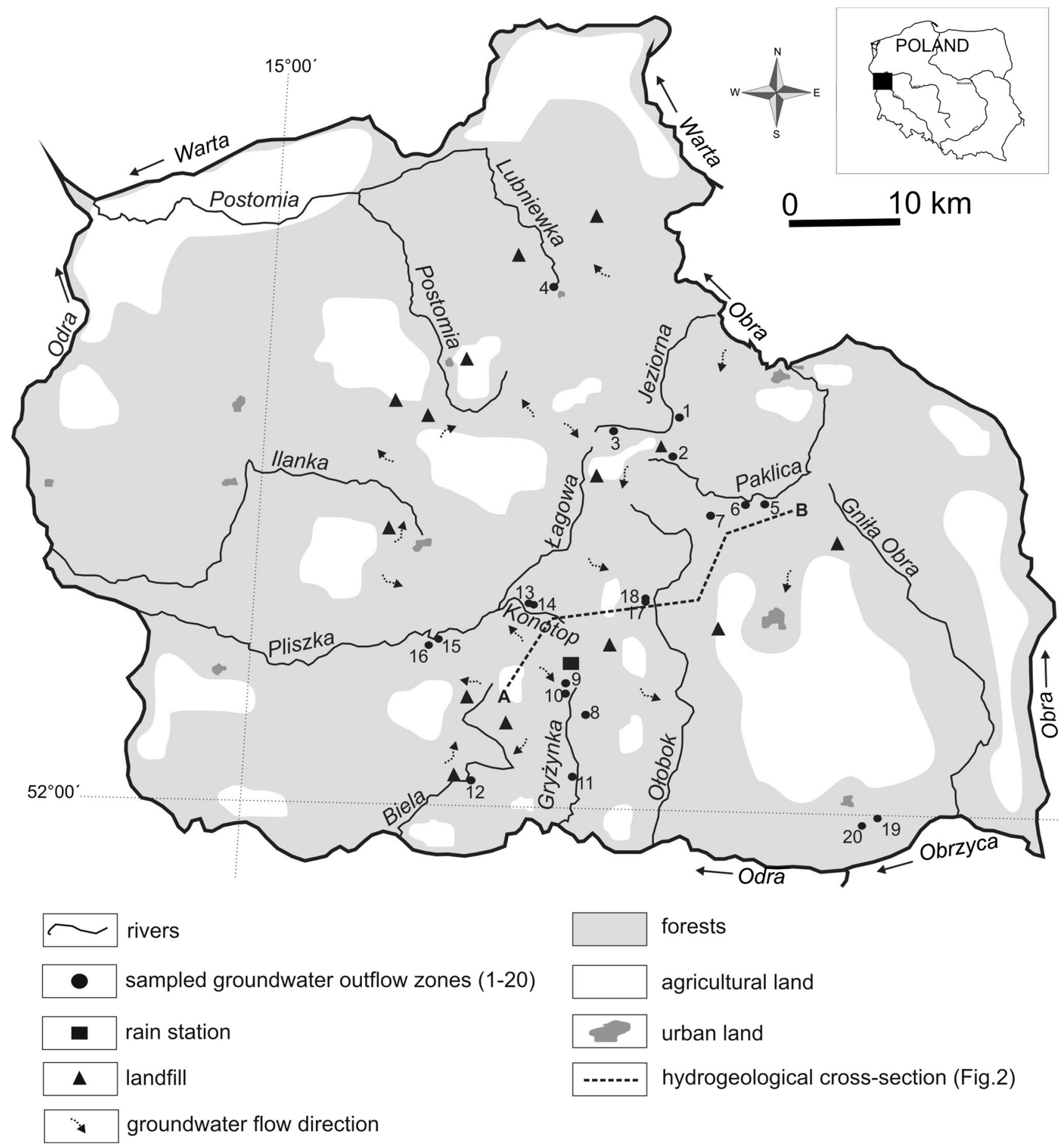

Fig. 1 Location of the studied groundwater outflows (springs) and the rainfall station, along with the land-use types (agricultural land/forests/ urban areas), the main directions of groundwater flow and landfill site locations

groundwater vulnerability to pollution is very high (aquifer vulnerable to most water pollutants were marked in Fig. 3) or high ( $85 \%$ of the remaining area) in the study area. The main causes of deterioration in groundwater quality are pollutants infiltrating from uncontrolled municipal waste landfills and from rural areas with no sanitary sewer systems. Pollution from intensive agriculture, mainly agrochemicals, also permeates into the groundwater. All these factors cause pollution of the first aquifer in the study area. To prevent further groundwater degradation, this area should be well monitored, because the main groundwater 


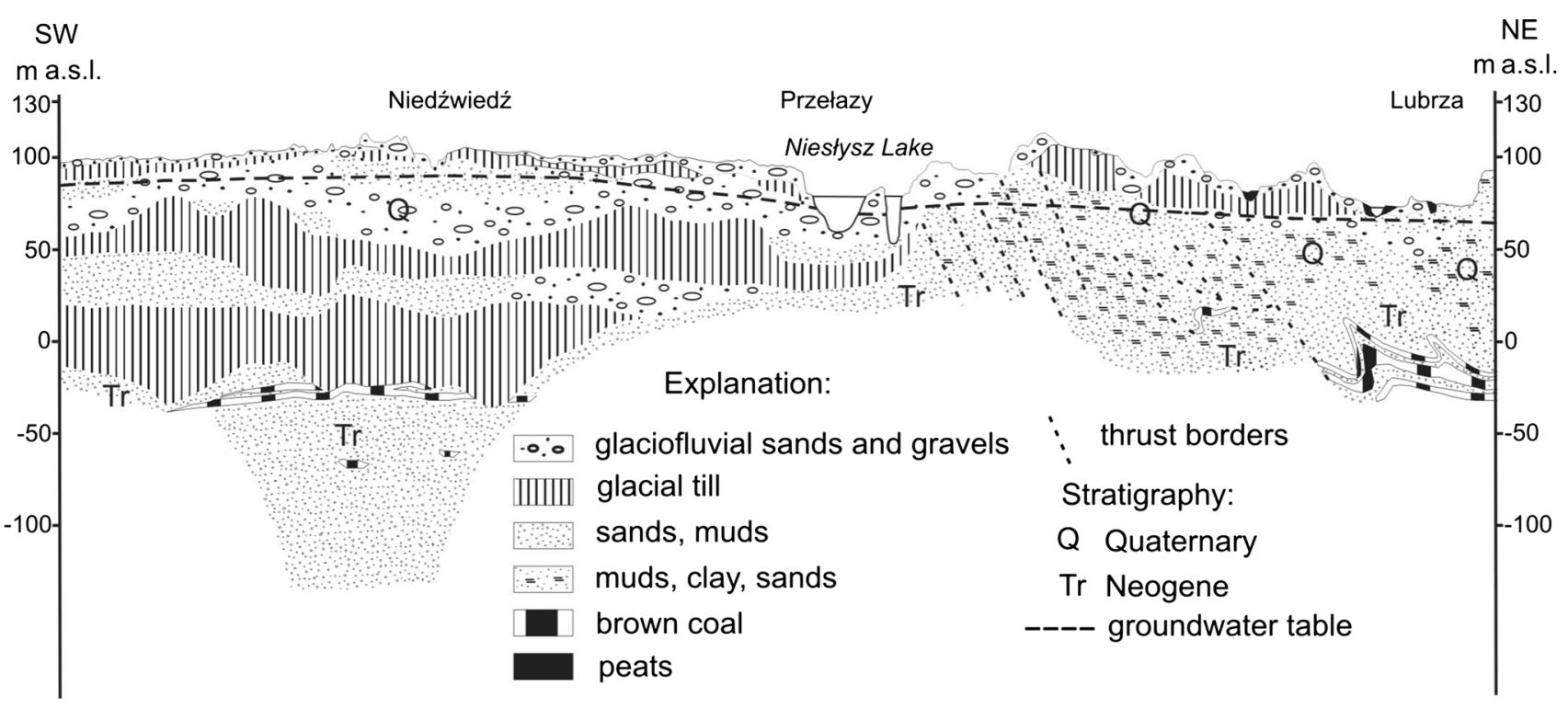

Fig. 2 Geological cross section of the study area indicating the position of the groundwater table

basins here require special protection (major groundwater basins-MGWB) (Fig. 3).

The Lubuska Upland is drained by rivers belonging to the Odra (Oder) catchment, the second longest river in Poland. They are characterized by a mixed snow-rainwater supply regime. An increase in their water levels occurs in early spring (March-April) due to snowmelt and in summer (July) due to increased rainfall. The lowest river water levels in the catchments of western Poland are observed in autumn (November). Groundwater predominates in the discharge of the rivers, contributing up to $80 \%$ of the annual total (Choiński 1981). Such a significant groundwater supply to the rivers is mainly due to favorable infiltration conditions in the outwash plains, which dominate in the area. Their infiltration coefficient ranges from $2 \times 10^{-6}$ to $9 \times 10^{-5} \mathrm{~m} / \mathrm{s}$. Many rivers of the Lubuska Upland often flow in tunnel valleys cut by subglacial streams during the last glaciation; therefore, the valleys are often deeply incised into the surface, down to 30-50 m. Groundwater outflows (springs and seeps) in the study area are mainly associated with such river valleys (Szczucińska 2014). They come from porous sediments, mainly sands and gravels, and are partly nourished by infiltrating water from present-day precipitation. The average annual temperature of spring water in the region is approximately $9{ }^{\circ} \mathrm{C}$, close to the mean annual air temperature of $8.2^{\circ} \mathrm{C}$ (Szczucinska and WasielewskI 2013).

The Lubuska Upland is regarded as the warmest region in Poland. The average air temperature in the entire voivodeship stands at approximately $8.5^{\circ} \mathrm{C}$. The average air temperature of the warmest (coolest) month of July (January) is $19(-1)^{\circ} \mathrm{C}$. The average annual precipitation ranges from 550 to $600 \mathrm{~mm}$. Snow cover is present for approximately 45 days a year (Woś 1999).

\section{Materials and methods}

\section{Water sampling}

In the mapping of the springs and seeps of the Lubuska Upland conducted from 2011 to 2013, approximately 180 zones of groundwater outflows were registered (Szczucińska 2014). Twenty were selected and studied in terms of the physicochemical properties of spring water. Various types of springs were selected, with different basic physicochemical parameters [temperature, specific electrical conductivity $(\mathrm{SpC})$, and $\mathrm{pH}]$, discharge and morphological location, and relatively easy access. In the period from November 2011 to October 2013, water samples were collected eight times from all the studied springs. The sampling occurred every 3-4 months. The samples were collected in polypropylene bottles with a capacity of $1 \mathrm{~L}$. Those for iron concentration measurements were collected in glass bottles. The subsamples for analyses of major cations and metals were treated with nitric acid. Temperature, specific electrical conductivity, and $\mathrm{pH}$ were also measured. The temperature was measured using an ETI electrical thermometer, with an accuracy of $0.1{ }^{\circ} \mathrm{C}$. Electrical conductivity was measured with an Elmetron CC-401 conductivity meter, with automatic compensation to a reference temperature of $25{ }^{\circ} \mathrm{C}$ and an accuracy of $\pm 0.1 \%$. The $\mathrm{pH}$ was measured with a handheld WTW $315 \mathrm{i} \mathrm{pH}$ meter, with an accuracy of $0.01 \mathrm{pH}$ units. 


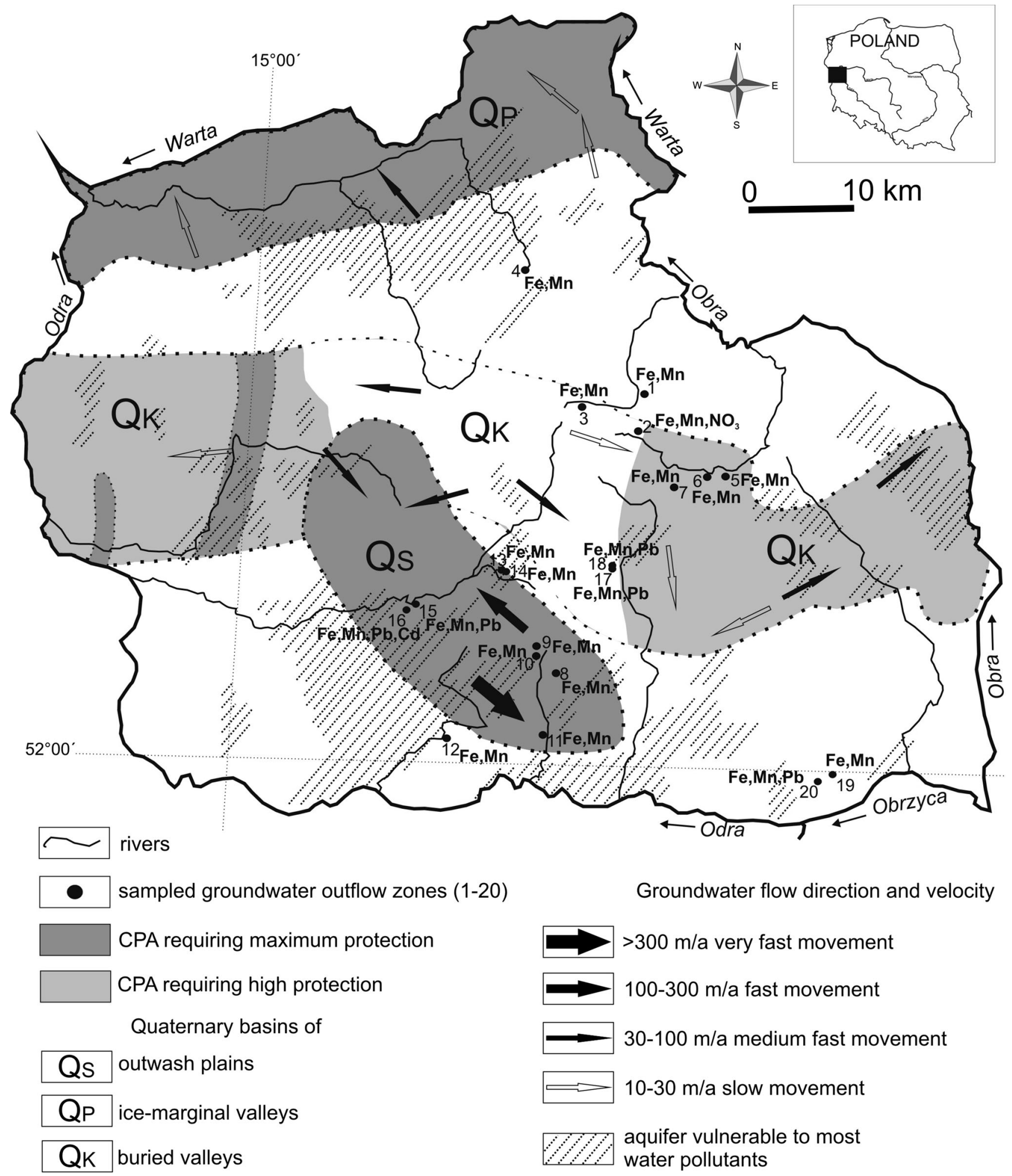

Fig. 3 Springs studied in the major groundwater basins that required special protection (Kleczkowski 1990). The observed parameters exceeded the limits for drinking water (according to WHO 2011) and groundwater vulnerable to water pollutants (Witczak et al. 2011) 


\section{Hydrochemical analyses}

The hydrochemical analyses were conducted in the certified Aquanet Laboratory of Environmental Research in Poznań, Poland. They were performed according to European standard regulations (norms) using the following methods:

- High-performance fluid chromatography (for $\mathrm{SO}_{4}{ }^{2-}$, $\mathrm{Cl}^{-}, \mathrm{PO}_{4}{ }^{3-}$, and $\mathrm{NO}_{3}{ }^{-}$),

- inductively coupled plasma mass spectrometry (ICPMS) (for $\mathrm{Na}^{+}, \mathrm{K}^{+}, \mathrm{Ca}^{2+}, \mathrm{Mg}^{2+}, \mathrm{Pb}^{2+}, \mathrm{Cd}^{2+}, \mathrm{Cu}^{2+}$, $\mathrm{Cr}^{3+}$, and $\mathrm{Zn}^{2+}$ ),

- spectrophotometry (for total $\mathrm{Fe}, \mathrm{NO}_{2}{ }^{-}$, and $\mathrm{NH}_{4}{ }^{+}$),

- atomic absorption spectrometry (AAS) (for $\mathrm{Mn}^{2+}$ ), and

- titration (for $\mathrm{HCO}_{3}{ }^{-}$and total water hardness).

The differences in the cation and anion balance did not exceed $5 \%$.

\section{Microbiological and bacteriological analyses}

Water samples for microbiological analysis were collected once from 13 springs. The analyses were also performed in the certified Aquanet Laboratory of Environmental Research in Poznań. Bacteria from the Coli group, studied using the filtration method, included Escherichia coli and Enterococci. The total number of organisms at a temperature of $36{ }^{\circ} \mathrm{C}$ was determined against the national standard (PN-EN ISO 6222:2004). Clostridium perfringens was determined in accordance with the Regulation of the Polish Minister of Health of 29 March, 2007 (Official Gazette no. 61, position 417).

\section{Isotopic study of nitrates}

For five spring samples (nos. 2, 3, 18, 19, and 20), analyses were conducted to determine the ratios of isotopic nitrogen $\left({ }^{15} \mathrm{~N} /{ }^{14} \mathrm{~N}\right)$ and oxygen $\left({ }^{18} \mathrm{O} /{ }^{16} \mathrm{O}\right)$ in the dissolved nitrates. These nitrates were converted into silver nitrate $\left(\mathrm{AgNO}_{3}\right)$, from which gaseous $\mathrm{N}_{2}$ was liberated to measure $\delta^{15} \mathrm{~N}$, or they were converted into $\mathrm{CO}_{2}$, which was then analyzed for the ${ }^{18} \mathrm{O}$ content. The uncertainties of the isotopic analyses performed were $\pm 0.4 \%$ for $\delta^{15} \mathrm{~N}$ and $\pm 0.8 \%$ for $\delta^{18} \mathrm{O}$.

\section{Data analysis}

The physical and chemical properties of water were analyzed using AquaChem 3.7 (for water types and the Piper diagram). Statistical analyses (e.g., factor analysis) were conducted using STATISTICA 10.

The average daily air temperature, measured at the meteorological station in Zielona Góra, located approximately $25 \mathrm{~km}$ southeast of the study area, was obtained from www.tutiempo.net. Daily precipitation totals, measured at the meteorological station at Gryżyna, were obtained from the Institute of Meteorology and Water Management (IMGW) (Fig. 1).

\section{Results}

The mean, minimum, and maximum values of water from the 20 selected springs sampled eight times between November 2011 and October 2013 are presented in Table 1 and Appendix 1. Moreover, Fig. 4 shows the seasonal variation of the selected parameters against the average daily values of air temperature and precipitation. Among the chemical parameters of spring water examined during the 2 years, seasonal changes were recorded for $\mathrm{Mn}^{2+}$ and total $\mathrm{Fe}$. The highest concentrations of $\mathrm{Mn}^{2+}(\mathrm{Fe})$ were observed in summer (autumn). In the case of nitrates, the highest concentrations occurred in autumn. However, in 2013, high levels were also noted in spring. For the remaining parameters under examination, no distinct seasonal variations were observed.

Table 1 Mean, maximum, and minimum values of water quality parameters for all the studied springs sampled seasonally in period from November 2011 to October 2013

\begin{tabular}{|c|c|c|c|}
\hline Parameter & Mean & Maximum & Minimum \\
\hline $\mathrm{pH}$ & 7.6 & 7.7 & 7.4 \\
\hline $\mathrm{EC}(\mu \mathrm{S} / \mathrm{cm})$ & 451 & 652 & 266 \\
\hline $\mathrm{Ca}^{2+}(\mathrm{mg} / \mathrm{L})$ & 78 & 113 & 45 \\
\hline $\mathrm{Mg}^{2+}(\mathrm{mg} / \mathrm{L})$ & 5.8 & 15.6 & 2.1 \\
\hline $\mathrm{Na}^{+}(\mathrm{mg} / \mathrm{L})$ & 7.0 & 12.5 & 4.0 \\
\hline $\mathrm{K}^{+}(\mathrm{mg} / \mathrm{L})$ & 1.2 & 2.4 & 0.6 \\
\hline $\mathrm{NH}_{4}^{+}(\mathrm{mg} / \mathrm{L})$ & 0.05 & 0.26 & 0 \\
\hline $\mathrm{HCO}_{3}^{-}(\mathrm{mg} / \mathrm{L})$ & 180 & 316 & 111 \\
\hline $\mathrm{SO}_{4}^{2-}(\mathrm{mg} / \mathrm{L})$ & 52 & 82 & 12 \\
\hline $\mathrm{Cl}^{-}(\mathrm{mg} / \mathrm{L})$ & 10.7 & 20.5 & 3.7 \\
\hline $\mathrm{NO}_{3}{ }^{-}(\mathrm{mg} / \mathrm{L})$ & 4.71 & 37.13 & 0.29 \\
\hline $\mathrm{NO}_{2}^{-}(\mathrm{mg} / \mathrm{L})$ & 0.01 & 0.03 & 0 \\
\hline $\mathrm{PO}_{4}{ }^{3-}(\mathrm{mg} / \mathrm{L})$ & 0.119 & 0.321 & 0.006 \\
\hline $\mathrm{Cd}^{2+}(\mathrm{mg} / \mathrm{L})$ & 0.0001 & 0.0007 & 0 \\
\hline $\mathrm{Cr}^{3+}(\mathrm{mg} / \mathrm{L})$ & 0.0005 & 0.0015 & 0.0001 \\
\hline $\mathrm{Cu}^{2+}(\mathrm{mg} / \mathrm{L})$ & 0.0020 & 0.0080 & 0.0003 \\
\hline $\mathrm{Fe}_{\text {tot }}(\mathrm{mg} / \mathrm{L})$ & 0.8 & 2.5 & 0.1 \\
\hline $\mathrm{Mn}^{2+}(\mathrm{mg} / \mathrm{L})$ & 0.24 & 1.11 & 0.03 \\
\hline $\mathrm{Pb}^{2+}(\mathrm{mg} / \mathrm{L})$ & 0.0042 & 0.0287 & 0.0002 \\
\hline $\mathrm{Zn}^{2+}(\mathrm{mg} / \mathrm{L})$ & 0.0056 & 0.0360 & 0.0012 \\
\hline TOC (mg/L) & 1.7 & 2.9 & 0.9 \\
\hline $\mathrm{TWH}\left(\mathrm{mgCaCO}_{3} / \mathrm{L}\right)$ & 218 & 329 & 131 \\
\hline
\end{tabular}

EC Electrical conductivity, TOC total organic carbon, TWH total water hardness 
Fig. 4 Seasonal changes in air temperature measured at Zielona Góra. The average seasonal $\mathrm{Pb}^{2+}, \mathrm{NO}_{3}{ }^{-}, \mathrm{NO}_{2}{ }^{-}$, total $\mathrm{Fe}$, and $\mathrm{Mn}^{2+}$

concentrations in the water of the 20 analyzed springs; and atmospheric precipitation $(P)$ recorded at the Gryżynka monitoring station
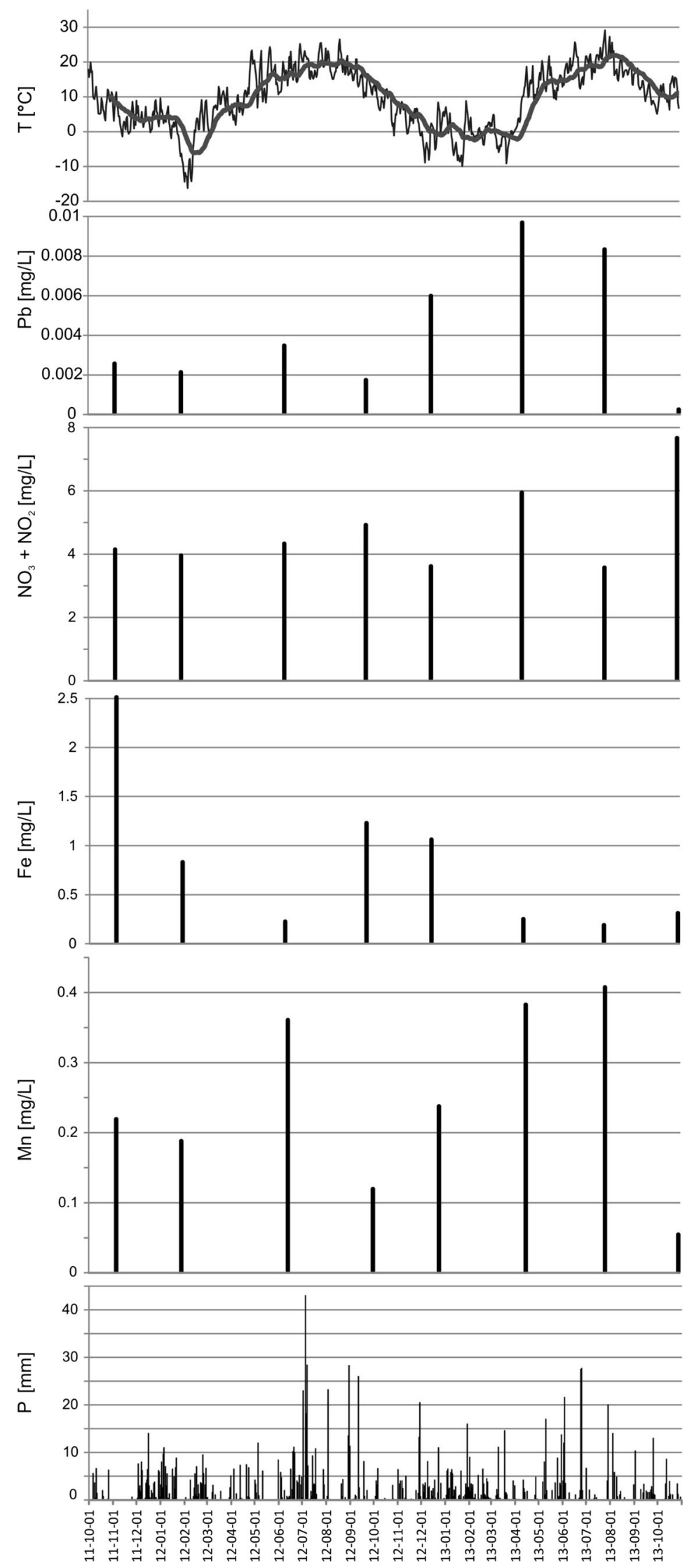
In the study area, there are two hydrochemical types of spring water, one dominated by $\mathrm{HCO}_{3}$ and $\mathrm{Ca}$ ions and the other by $\mathrm{SO}_{4}$ (Fig. 5). According to Hem's (1989) hydrogeochemical classification, which considers the absolute presence of ions in water $>20 \%$ mval, this water belongs to the $\mathrm{Ca}-\mathrm{HCO}_{3}-\mathrm{SO}_{4}(70 \%)$ and $\mathrm{Ca}-\mathrm{HCO}_{3}(30 \%)$ types.

The average $\mathrm{pH}$ values of spring water ranged from 7.46 to 7.71 , classified as the slightly alkaline class. This water is medium-hard, with an average total hardness varying between 213- and 228-mg $\mathrm{CaCO}_{3} / \mathrm{L}$. The average spring water temperature in the studied 2-year period was $9.6^{\circ} \mathrm{C}$, close to the average air temperature in the region of $8.2^{\circ} \mathrm{C}$. The average value of electrical conductivity was $451 \pm 15 \mu \mathrm{S} / \mathrm{cm}$, which indicates low mineralization of these waters.

Among the cations, the highest variability in concentration was found in the case of iron and ammonium ions. The iron concentration varied from approximately 0-14 mg/L, whereas that of ammonium varied from 0 to $0.37 \mathrm{mg} / \mathrm{L}$. The $\mathrm{Mn}^{2+}, \mathrm{Pb}^{2+}, \mathrm{Zn}^{2+}$, and $\mathrm{Cu}^{2+}$ concentrations varied considerably during the study period. The concentrations varied from approximately 0-to-4.2$\mathrm{mg} \mathrm{Mn} / \mathrm{L}$, from approximately 0 -to-0.1-mg $\mathrm{Pb} / \mathrm{L}$, from 0.0001-to-0.16-mg $\mathrm{Zn} / \mathrm{L}$, and from approximately 0-to0.03-mg Cu/L, respectively. Among the anions, the highest variability in concentration was found for $\mathrm{NO}_{2}{ }^{-}, \mathrm{NO}_{3}{ }^{-}$, and $\mathrm{PO}_{4}^{3}$. These parameters were within the ranges of 0-to0.18-mg $\mathrm{NO}_{2} / \mathrm{L}, \quad 0$-to-74-mg $\mathrm{NO}_{3} / \mathrm{L}, \quad$ and 0 -to-0.86$\mathrm{mg} \mathrm{PO}_{4} / \mathrm{L}$, respectively.

Despite the high variability of the concentrations of the examined spring water parameters, only a few exceeded the Polish standards for drinking water. Those that did included $\mathrm{Mn}^{2+}$ and total Fe. Levels in excess of the limits for drinking water were found in at least $75 \%$ of the analyses, in 13 springs for $\mathrm{Mn}^{2+}$, and in 8 springs for total Fe. The highest $\mathrm{Mn}^{2+}$ concentration $(4.2 \mathrm{mg} / \mathrm{L})$ was observed in spring no. 1 , and the highest total Fe (14 mg/L) concentration occurred in spring no. 18. The Polish standards for drinking water put the limit for the $\mathrm{Mn}^{2+}$ concentration at $0.05 \mathrm{mg} / \mathrm{L}$ and for total $\mathrm{Fe}$ at $0.2 \mathrm{mg} / \mathrm{L}$. Concentrations

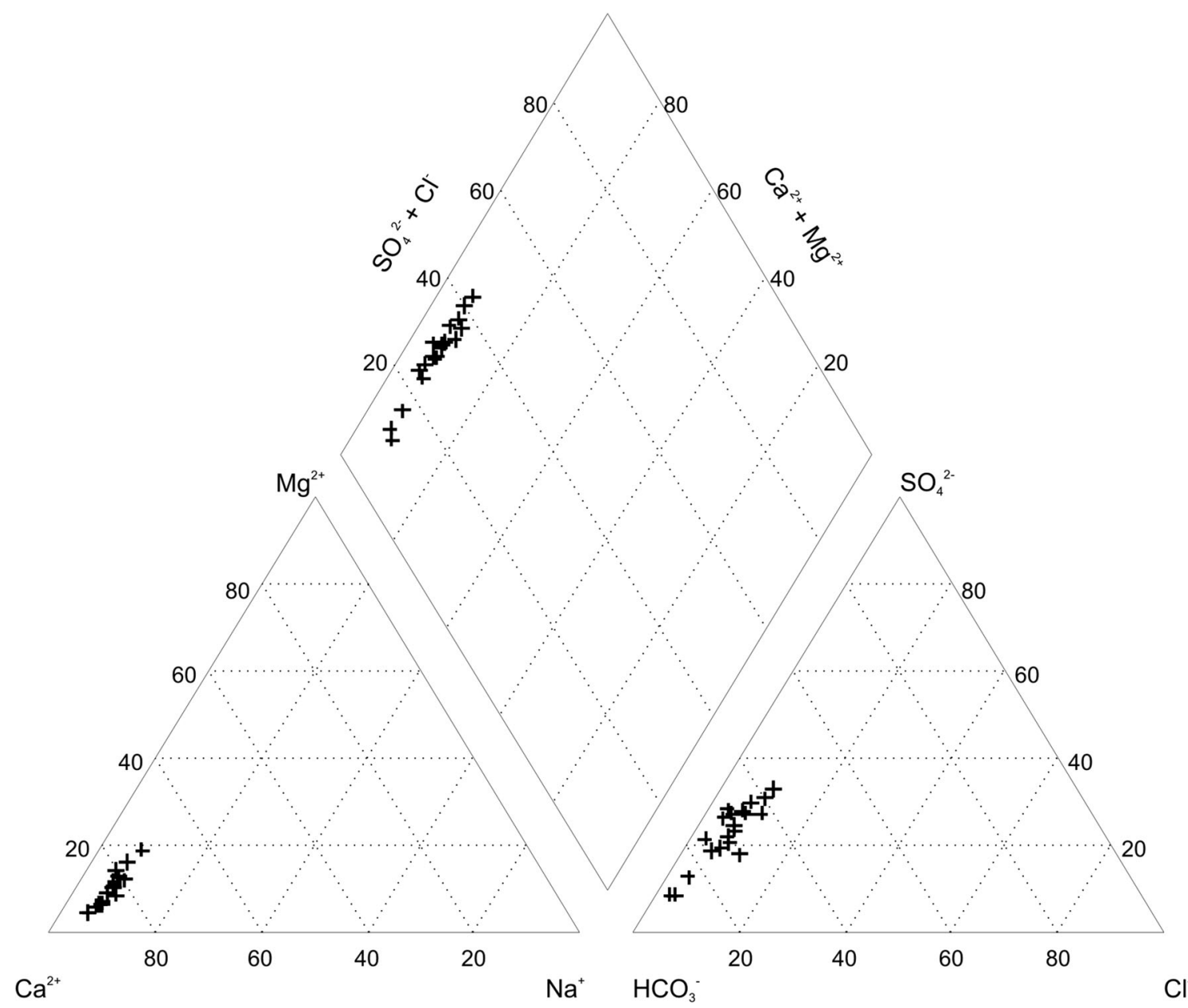

Fig. 5 Piper diagram of the major components of spring water in the Lubuska Upland area, with the composition of the analyzed spring water samples 
Table 2 Microbiological tests of Lubuska Upland spring waters

\begin{tabular}{lclccc}
\hline $\begin{array}{l}\text { Sampling site } \\
\text { (spring no.) }\end{array}$ & $\begin{array}{l}\text { Bacteria from Coli } \\
\text { group }(\mathrm{cfu} / 100 \mathrm{~mL})\end{array}$ & $\begin{array}{l}\text { Escherichia coli } \\
(\mathrm{cfu} / 100 \mathrm{~mL})\end{array}$ & $\begin{array}{l}\text { Total number of } \\
\text { microorganisms } \\
(\mathrm{cfu} / 1 \mathrm{~mL})\end{array}$ & $\begin{array}{l}\text { Clostridium perfringens } \\
(\mathrm{cfu} / 100 \mathrm{~mL})\end{array}$ & $\begin{array}{l}\text { Enterococcus } \\
(\mathrm{cfu} / 100 \mathrm{~mL})\end{array}$ \\
\hline 1 & 64 & 1 & 16 & 0 & 0 \\
2 & 488 & 1 & 134 & 1 & 0 \\
4 & 2 & 0 & 4 & 0 & 0 \\
5 & 96 & 0 & 24 & 0 & 0 \\
6 & 39 & 0 & 35 & 0 & 1 \\
8 & 79 & 0 & 27 & 0 & 0 \\
9 & 281 & 1 & 23 & 0 & 0 \\
10 & 78 & 0 & 5 & 0 & 0 \\
11 & 228 & 0 & 4 & 0 & 0 \\
15 & 268 & 2 & 122 & 4 & 0 \\
16 & 2420 & 1 & 161 & 0 & 2 \\
17 & 197 & 0 & 27 & 10 & 0 \\
\hline
\end{tabular}

$C f u$ colony forming unit per $100 \mathrm{~mL}$ of water

Table 3 Results of the analysis of the isotopic composition of nitrate $\left(\delta^{15} \mathrm{~N}\right.$ and $\left.\delta^{18} \mathrm{O}\right)$ in spring water samples

\begin{tabular}{|c|c|c|c|}
\hline \multirow[t]{2}{*}{ Spring no. } & \multirow[t]{2}{*}{$\mathrm{NO}_{3}{ }^{-}(\mathrm{mg} / \mathrm{L})$} & \multicolumn{2}{|c|}{ Dissolved nitrates } \\
\hline & & $\delta^{15} \mathrm{~N}_{\text {air }}(\% o)$ & $\delta^{18} \mathrm{O}_{\mathrm{V} \_ \text {SMOW }}(\%)$ \\
\hline 2 & 28.4 & +4.4 & +7.6 \\
\hline 3 & 4.8 & +8.3 & +10.8 \\
\hline 18 & 7.0 & +3.3 & +6.8 \\
\hline 19 & 5.4 & +5.9 & +8.5 \\
\hline 20 & 15.5 & +9.4 & +9.6 \\
\hline
\end{tabular}

exceeding the Polish standards were also found in four springs in the case of $\mathrm{Pb}^{2+}$. The permissible concentration of lead in drinking water is $0.01 \mathrm{mg} / \mathrm{L}$, which was exceeded three times in springs no. 15 and 20 and in a single analysis of springs no. 16 and 18. A tenfold excess of the $\mathrm{Pb}^{2+}$ limit was recorded in spring no. 15. In addition, in spring no. 2, nitrates were once observed to exceed the standards for drinking water $(50 \mathrm{mg} / \mathrm{L})$, amounting to $74 \mathrm{mg} / \mathrm{L}$. This spring also showed a gradual increase in nitrate concentrations during the study period.

The results of the microbiological tests of spring water are shown in Table 2. All 13 analyzed springs do not meet the criteria for drinking water, except spring no. 2. There are two reasons for the generally poor microbiological quality of the water. First, it contains coliform bacteria (with a standard of $0 \mathrm{cfu} / 100 \mathrm{~mL}$ ). Second, the total number of microorganisms in the water exceeds the limit of $50 \mathrm{cfu} / \mathrm{mL}$. The highest levels of bacteria were found in springs no. 16,18 , and 2 .
The analysis results of the isotopic composition of nitrates $\left(\delta^{15} \mathrm{~N}\right.$ and $\left.\delta^{18} \mathrm{O}\right)$ in the spring water are listed in Table 3. The variability of the composition ranged from +3.3 in spring no. 18 to +9.4 in spring no. 20 . In addition, Fig. 6 shows the relationship between the isotopic composition of oxygen $\left(\delta^{18} \mathrm{O}\right)$ and the isotopic composition of nitrogen $\left(\delta^{15} \mathrm{~N}\right)$ in the examined nitrates. The straight line presents one of the possible trajectories of the evolution of the isotopic composition of nitrates in the process of denitrification. The location of the measuring points along this line strongly suggests denitrification of nitrates that are of agricultural origin. However, the location of points along the denitrification line is not correlated with the nitrate content of the water samples (Table 3), which is indicative of an additional $\mathrm{NO}_{3}{ }^{-}$source.

\section{Discussion}

\section{Variability of major components and nutrients in spring water}

The physicochemical properties of the analyzed spring water are typical for water bodies fed from glacial and glaciofluvial deposits. Thus, their chemical composition is dominated by calcium ions and bicarbonates released during the weathering of aluminum silicates and the dissolution of calcium carbonate. Important is also contribution of organic matter being source of some major ions. Many authors (e.g., Nowicki and Sadurski 2010) claim that the dominant hydrochemical type $\mathrm{Ca}-\mathrm{HCO}_{3}$ is typical of shallow Quaternary groundwater in the active exchange 


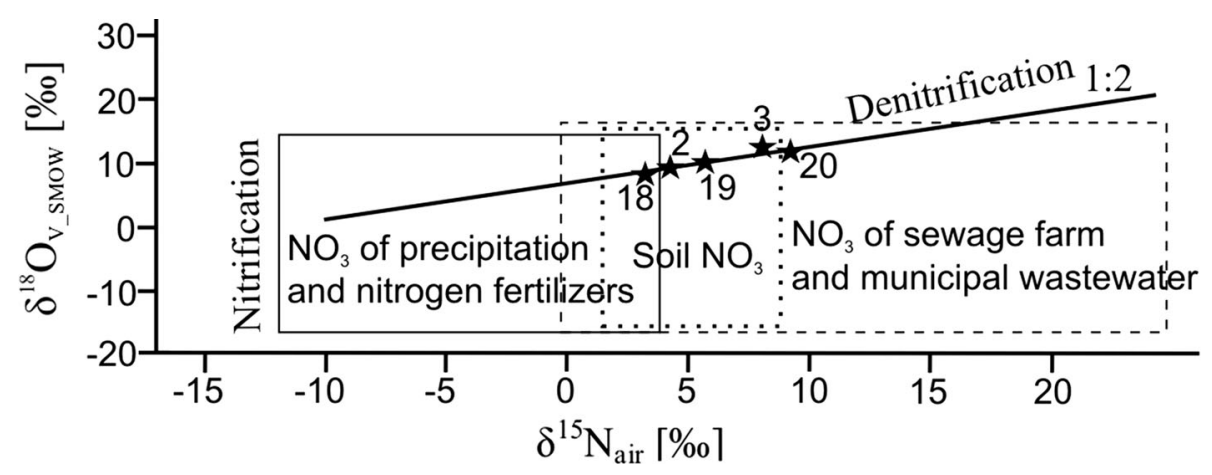

Fig. 6 Dependence of the isotopic composition of oxygen in nitrates $\left(\delta^{18} \mathrm{O}\right)$ on the isotopic composition of nitrogen $\left(\delta^{15} \mathrm{~N}\right)$ in the spring water under study (springs no. 2, 3, 18, 19, and 20). Typical ranges of variation in the isotopic composition of nitrates at various stages of the nitrogen cycle in the environment derived from precipitation and

zone (the zone affected by natural and anthropogenic processes). Moreover, the results indicate that the water has not been transformed significantly by anthropogenic activities, because strongly transformed water, as observed in the post-glacial areas of northwestern Poland by Mazurek (2008), is characterized by high concentrations of nitrate ions in addition to calcium and bicarbonate ions.

The parameters determining the hydrochemical water type (Fig. 5), namely, $\mathrm{Ca}^{2+}, \mathrm{Mg}^{2+}, \mathrm{K}^{+}, \mathrm{Na}^{+}, \mathrm{HCO}_{3}, \mathrm{Cl}^{-}$, and $\mathrm{SO}_{4}{ }^{2-}$, showed low seasonal variability. The observed slight changes in the concentrations of these parameters were associated with changes in spring discharge caused by changes in the rainwater or snowmelt supplies. This caused a slight decrease in $\mathrm{Ca}^{2+}, \mathrm{Mg}^{2+}$, and $\mathrm{HCO}_{3}$ concentrations, as well as a slight increase in $\mathrm{K}^{+}, \mathrm{Na}^{+}$, and $\mathrm{SO}_{4}{ }^{2-}$ concentrations. The seasonal variations of the major components of the groundwater are also influenced by chemical sorption, understand here as seasonal binding of watersoluble compounds (mainly sulfates and carbonates) in soils. The next potentially important process is sorption of exchangeable cations: $\mathrm{Ca}^{2+}, \mathrm{Mg}^{2+}, \mathrm{K}^{+}, \mathrm{Na}^{+}$, and $\mathrm{H}^{+}$. The highest temporal variability was found for nutrients, mainly $\mathrm{PO}_{4}{ }^{3-}, \mathrm{NO}_{3}{ }^{-}$, and $\mathrm{NO}_{2}{ }^{-}$(Fig. 4). The variability was influenced by both natural (e.g., biological cycles and water table changes) and anthropogenic (e.g., supply by fertilizers, infiltration of polluted rainwater) factors.

Natural factors influencing the variability of $\mathrm{PO}_{4}{ }^{3-}$, $\mathrm{NO}_{3}{ }^{-}$, and $\mathrm{NO}_{2}{ }^{-}$are considered to be associated with nitrogen and phosphorus cycling in the soil (biological sorption), especially during the growing season, when plants take up these macronutrients, mainly nitrogen, phosphorus, and potassium, from water (Kabata-Pendias and Pendias 1999). However, nitrate in soil moves quickly with infiltration, which is an additional factor affecting these changes. The spatial variability, especially of $\mathrm{NO}_{3}{ }^{-}$ and $\mathrm{NO}_{2}{ }^{-}$, as suggested by Ouyang et al. (2013) and César nitrogenous fertilizers, nitrification of ammonia compounds and organic matter in the soil and from municipal and household waste. The straight line with a 1:2 inclination shows a rough trajectory of the evolution of the isotopic composition of nitrates dissolved in the nitrification process

et al. (2014), can also result from the land-use pattern. Hence, the concentration of those parameters generally tended to be lower in summer. In turn, the highest concentrations, especially of nitrogen compounds, were observed in autumn when water could be enriched as a result of the decomposition of dead plant debris. Changes in nitrate concentrations can also be associated with fluctuations in the shallow groundwater level. In periods without rain, nitrates can accumulate in the aeration zone; after a rainfall event or the occurrence of snowmelt, the infiltrating water permeates into the shallow aquifers drained by springs. Reductions in nitrate concentrations in spring waters can occur with decreases in the water table. Increasing water table depth decreases the amount of oxygen, subsequently reducing bacterial activity and, thereby, decreasing nutrient concentrations. Slight water pollution by nitrates may also originate from atmospheric precipitation. The highest nitrate level in precipitation in the area of approximately $1 \mathrm{mg} / \mathrm{L}$ was recorded in spring (Liana 2013). Therefore, the elevated nitrate levels in the examined spring water observed in September 2012 could partly result from the significant rainfall that occurred several weeks before sampling, amounting to $250 \mathrm{~mm}$, or $40 \%$ of the annual rainfall. The human-related pollution of spring water with nitrates can also be caused by the leaching of nitrogen compounds from farmland located in the vicinity of the groundwater outflows. Five of the studied springs that had the highest average concentrations of $\mathrm{NO}_{3}{ }^{-}$were also analyzed in terms of nitrogen isotopes (Fig. 6). All the studied spring waters are in the range of values of isotopic composition of nitrate typical for wastewater and domestic livestock. However, some of the results also fall in the overlapping fields typical for precipitation and used in agriculture nitrogenous fertilizers (spring no. 18), as well as in the field characteristic processes of nitrification and mineralization of organic matter 
in soils (springs no. 2, 3, 19, and 20). The precise determination of the source of nitrates in springs of Lubuska Upland requires further study.

\section{Trace element variability in spring water}

Total $\mathrm{Fe}$ and $\mathrm{Mn}^{2+}$ both display seasonal variation. Although the correlation coefficient of iron and manganese in the analyzed samples is high (0.63) due to the natural geochemical affinity of these metals, manganese is characterized by greater stability.

The highest $\mathrm{Fe}\left(\mathrm{Mn}^{2+}\right)$ concentration was noted in autumn (summer). During the study period, in approximately $80 \%$ of the springs, much higher levels of iron were observed in the autumn of 2011, which can be associated with increased amounts of decomposing organic matter. This was the situation in November 2011, when the spring water had the highest iron content.

It should be noted, however, that the iron concentration in water may vary substantially, even within the same aquifer (Idoko 2010), which significantly affects the interpretation of its seasonal variability. The mosaic phenomenon of spatial and temporal variation of iron content in the spring waters was also observed by Mazurek et al. (2014). Particularly, changes caused by the variability in $\mathrm{pH}$ and in the redox potential (Walna and Siepak 2012) are important. In the studied springs, the occurrence of moderate redox conditions (averaging $424 \mathrm{mV}$ ) is conducive to the water migration of iron and manganese. It was also observed that the iron and manganese contents were lower in the springs supplied from sediments not covered by glacial till in comparison with those supplied by the sediments covered with glacial till.

In Poland, iron concentrations often exceed the national legal regulations for tap water (more than $0.2 \mathrm{mg} / \mathrm{L}$ ). It is estimated that the average concentration of iron in water present in glaciofluvial sands is $2.06 \mathrm{mg} / \mathrm{L}$ and varies from 0.03 to $10 \mathrm{mg} / \mathrm{L}$ (Macioszczyk and Dobrzynski 2007). In the Lubuska Upland area, the mean concentration of total Fe in the springs was $0.8 \mathrm{mg} / \mathrm{L}$ over the 2 years of study, although the mean concentrations in the individual springs ranged from 0.1 to $2.5 \mathrm{mg} / \mathrm{L}$, attaining a maximum of $14 \mathrm{mg} / \mathrm{L}$ in spring no. 18 . Relative to adjacent areas, the higher iron and manganese concentrations in the study region influenced the lower carbonate content in the Quaternary sediments. The lower carbonate content reduces the buffering capacity of the soils against acidifying factors. In addition, the study area is dominated by sandy soils, and characterized by a low buffering and weak capability of binding trace elements. Such a situation is conducive to the leaching of these elements into groundwater. The investigated spring waters also showed marked variability in trace element concentrations, such as zinc, copper, cadmium, chromium, and lead. It may also be an effect of the low buffering capacity of soils and near surface sediments, because the trace elements are preferentially released in conditions of lowered $\mathrm{pH}$, for instance, in a result of an acid rain. Lead is particularly noteworthy here, as its maximum concentrations were above the national legal limits for drinking water. According to Kabata-Pendias and Pendias (1999), the average concentration of lead in groundwater in Poland is $0.04 \mathrm{mg} / \mathrm{L}$ or less, because lead is also sorbed in the vadose zone and in aquifer sediments themselves. The mentioned authors estimated that approximately $70 \%$ of lead delivered to groundwater originated from atmospheric precipitation. In addition, Upadhyaya et al. (2013) concluded that the $\mathrm{Pb}^{2+}$ level in groundwater can be the result of its deposition from the atmosphere. In this study, the highest observed concentration of lead in spring water was found during the winterspring period of 2013. Probably, the main reason for its elevated levels was a long period of low air temperatures, which prolonged the heating season and, thus, increased lead emissions into the atmosphere. This is confirmed by the results of research conducted at the monitoring site in Zielona Góra (approximately $25 \mathrm{~km}$ from the study area), where the average recorded concentration of lead in atmospheric precipitation during this period was $0.0053 \mathrm{mg} / \mathrm{L}$, whereas the mean for the remaining months was $0.002 \mathrm{mg} / \mathrm{L}$ (Liana 2013). Moreover, the high levels of lead in spring water could also be partly due to the timing of melting of a particularly persistent snow cover, which could contribute to the rapid delivery of lead into groundwater (Walna and Siepak 2012). In the case of spring no. 15 , long-term high concentrations of lead were also observed in the summer of 2013. Because this element is considered to be a weak migrant in aquatic environments, it is likely that its source is located in the vicinity of the spring, and its elevated levels can be associated with anthropogenic pollution. The lead may derive from farmland located approximately $200 \mathrm{~m}$ from the spring, where crop protection products are used. A potential source of lead and other substances that cause groundwater contamination may be leaking of pollutants from landfills present in the study area. However, the assessment of their migration is complicated because of the complexity of the physical, chemical, and biological processes taking place in soils and in underlying sediments. Within the study area, in the areas nearest to the landfills, groundwater contamination was found (Lubrza Sozological Map, 2002). However, no further migration of the pollutants toward groundwater outflow zones was studied. Evaluation of the impact of landfills on groundwater is also limited. The legal regulations require monitoring of groundwater in the area of landfills, including usually only the $\mathrm{pH}$ and SPC measurements. Only in some cases, the monitoring includes 
also total organic carbon, polycyclic aromatic hydrocarbons (PAHs), and selected trace elements (Regulation of the Ministry of Environment 2002). However, the data from the monitoring are not published for the study area. It is likely, that springs no. 2, 17 and 18, which are located in the vicinity of landfills, may be exposed to pollutants (e.g., lead) of landfill origin but since the springs are also exposed to pollutants from agriculture area it is not possible to identify the source with certainty. Lead is toxic to the human body and is considered to be harmful to aquatic ecosystems (Kabata-Pendias and Pendias 1999), so this research should be followed by more detailed studies of the lead content in the groundwater of the Lubuska Upland area. Particular attention should be given to areas for which the reported concentrations of lead were found to exceed the Polish standard for drinking water of $0.01 \mathrm{mg} / \mathrm{L}$. As the present research has demonstrated, these are primarily areas in the drainage basins of the Pliszka and Ołobok rivers (the Lake Niesłysz region). The variability of selected heavy metals in spring water was already found not only in the Gryżynka river catchment of the Lubuska Upland in the previous work (Szczucińska et al. 2010) but also in springs near Poznań in western Poland (Walna and Siepak 2012). Walna and Siepak (2012) interpret the variability as caused by both natural processes (long-lasting precipitation that allows for immobile forms of trace elements to become mobile; changes in $\mathrm{pH}$ ) and anthropogenic factors (mainly agriculture).

On the basis of the conducted research, one can conclude that measurements, especially of the trace element concentrations, should be taken several times per year. The Polish Minister of the Environment's Regulation on groundwater monitoring requires water to be sampled at least twice per year, which is insufficient the case of the study area.

\section{Factor analysis for the hydrogeochemical study of spring water}

To identify factors influencing the chemical composition of the studied spring water, factor analysis was conducted. This method has been used by many authors (e.g., Giridharan et al. 2008; Love et al. 2004; Reghunath et al. 2002; Kumar et al. 2009; Aghazadeh and Mogaddam 2011; and Tallini et al. 2013) to analyze factors and processes involved in the formation of the chemical properties of water. In assessing average values of the 13 physicochemical parameters of water from the 20 springs, four complementary components were identified (Table 4). Together, they accounted for $86 \%$ of the variation observed in the groundwater characteristics in the study area. Factor 1 accounts for the largest share of the variability of the spring water chemistry, explaining $44 \%$. Factors 2 and 3 account
Table 4 Factor analysis of the all the hydrochemical data on spring waters

\begin{tabular}{llll}
\hline Factor & Eigen values & \% Variance & Cumulative \% \\
\hline 1 & 5.685 & 43.729 & 43.729 \\
2 & 2.269 & 17.454 & 61.183 \\
3 & 1.871 & 14.389 & 75.572 \\
4 & 1.328 & 10.217 & 85.789 \\
\hline
\end{tabular}

Factors with eigenvalues greater than one and their percentage of variance and cumulative percentage of variance in the factor analysis are presented

Table 5 Loadings reflecting the effect of individual variables on the given principal component

\begin{tabular}{|c|c|c|c|c|}
\hline \multicolumn{5}{|c|}{ Rotated component matrix } \\
\hline \multirow[t]{2}{*}{ Variables } & \multicolumn{4}{|c|}{ Factors loading } \\
\hline & Factor 1 & Factor 2 & Factor 3 & Factor 4 \\
\hline EC & 0.988 & 0.057 & 0.022 & 0.005 \\
\hline $\mathrm{Ca}^{2+}$ & 0.930 & 0.259 & -0.038 & -0.095 \\
\hline $\mathrm{Na}^{+}$ & 0.895 & -0.242 & 0.013 & 0.155 \\
\hline $\mathrm{HCO}_{3}{ }^{-}$ & 0.880 & -0.078 & -0.328 & 0.278 \\
\hline $\mathrm{Mg}^{2+}$ & 0.845 & -0.285 & -0.131 & 0.379 \\
\hline $\mathrm{K}^{+}$ & 0.754 & -0.257 & 0.282 & 0.290 \\
\hline $\mathrm{SO}_{4}{ }^{2-}$ & 0.518 & 0.387 & 0.249 & -0.337 \\
\hline $\mathrm{Mn}^{2+}$ & 0.505 & 0.464 & -0.428 & -0.372 \\
\hline $\mathrm{Pb}^{2+}$ & -0.046 & 0.904 & 0.211 & 0.334 \\
\hline $\mathrm{Zn}^{2+}$ & -0.091 & 0.831 & 0.215 & 0.470 \\
\hline $\mathrm{NO}_{3}{ }^{-}$ & 0.281 & -0.103 & 0.753 & -0.134 \\
\hline Total Fe & 0.263 & 0.307 & -0.709 & -0.273 \\
\hline $\mathrm{Cl}^{-}$ & 0.549 & 0.096 & 0.510 & -0.560 \\
\hline
\end{tabular}

for 17 and $14 \%$ of the variation of the analyzed parameters, respectively. Factor 1 can be related to major components of the spring water (Table 5). One of the main components of glacial and glaciofluvial sediments is calcium carbonate, which is easily dissolved by infiltrating water. In addition, the mineral composition of these sediments permits the weathering of aluminosilicate and ion exchange. Common in these processes are the release and leaching of ions, particularly $\mathrm{Ca}^{2+}, \mathrm{Mg}^{2+}, \mathrm{Na}^{+}, \mathrm{K}^{+}$, and $\mathrm{HCO}_{3}{ }^{-}$, causing an increase in the total mineralization of spring water. This is reflected in the strong correlation between factor 1 and electrical conductivity. Factors 2 and 3 are associated mainly with the variability in the levels of lead and nitrates, which may indicate their anthropogenic origin in the spring water. As revealed by isotopic analyses of nitrates in the water, apart from punctual anthropogenic sources, $\mathrm{NO}_{3}{ }^{-}$can also be related to biogeochemical factors (Fig. 6). However, nitrates released due to the mineralization of organic matter are present in natural water at 
very low concentrations, typically under $1 \mathrm{mg} / \mathrm{L}$. Among the studied springs, $50 \%$ are characterized by mean nitrate concentrations below $1 \mathrm{mg} / \mathrm{L}$, which is within the range of natural hydrogeochemical background values for Poland (Witczak and Adamczyk 1995). During the study period, the average nitrate levels in the other springs ranged from 0.29 to $37 \mathrm{mg} / \mathrm{L}$, but an upward trend could be observed, especially in spring no. 2. This suggests a steady input of pollutants into the groundwater, which should be controlled in future studies. In the groundwater of the nearby area (east of the Lubuska Upland), Dragon (2013) documented high nitrate concentrations in excess of the Polish limit for drinking water and WHO standards.

\section{Microbiological testing of spring water}

The substandard quality of groundwater flowing from some of the springs was also confirmed by microbiological tests. However, it should be emphasized that these analyses were only conducted once, and only for 13 of the 20 springs. Particularly, high concentrations of bacteria were recorded in springs no. 2, 16, and 18. The coliform bacteria found in the water indicate organic pollution, but most of the bacteria are not harmful to humans. However, their presence indicates the potential occurrence of other pathogenic bacteria in the water, e.g., Escherichia coli and Clostridium perfringens, which were identified in springs no. 1, 2, 9, 15, and 16 and no. 2, 16, and 18, respectively. The presence of these two groups of bacteria in spring water may indicate pollution with sewage. In springs no. $2,15,16$, and 18 , the total number of microorganisms was more than double the acceptable drinking water standard of $50 \mathrm{cfu} / \mathrm{mL}$. The close proximity of springs in better or worse bacteriological conditions may indicate the local character of the pollution. However, the particularly poor sanitary states of springs no. 2, 15, 16, and 18 are correlated with high nitrate and lead levels. Thus, the pollutants may be derived from improper wastewater management and agricultural activities in the region.

\section{Conclusions}

This study provides the first regional assessment of seasonal variations in spring water hydrochemistry for groundwater outflows in the Lubuska Upland area (western Poland). The key findings are as follows.

- The chemical composition of the majority of studied spring water samples is mainly controlled by natural geogenic factors related to the characteristics of the aquifer system dominated by sediments and landforms of the Late Pleistocene glaciations.
- Most of the studied elements displayed slight seasonal variations, except for some trace elements $\left(\mathrm{Pb}^{2+}\right.$, $\mathrm{Mn}^{2+}$, total $\left.\mathrm{Fe}\right)$ and nutrients $\left(\mathrm{NO}_{3}{ }^{-}\right)$.

- In some of the springs, local anthropogenic groundwater pollution was found (high seasonal $\mathrm{NO}_{3}{ }^{-}$and $\mathrm{Pb}^{2+}$ concentrations and poor microbiological status), which was likely mainly due to improperly conducted agricultural activities.

- During the winter-spring period, $\mathrm{Pb}^{2+}$ concentrations are even ten times higher than the Polish standards for drinking water, which is probably due to atmospheric precipitation as well as drainage from agricultural areas.

- Geogenic contamination common in all the springs includes high seasonal concentrations of iron and manganese found to exceed the Polish limits for drinking water.

Thus, it could be concluded that the groundwater of the study area is not greatly polluted. However, the seasonal concentrations of trace elements are in excess of drinking water standards, and require water treatment actions. This is particularly important, because the groundwater from Quaternary aquifers is the primary source of water for the population living in the study area. The present regional monitoring system of the groundwater using spring water analyses may be highly insufficient, as it is based on annual or biannual sampling only, which may not identify seasonal fluctuations of the trace elements and nitrate. An important issue to be considered for groundwater protection in this region is high permeability of the surface sediments. It causes that most of contaminants contained in rainfall as well as in sewage may be easily transported into groundwater.

Acknowledgments This study was funded by Ministry of Science and Higher Education (Grant Number NN306 035040). I cordially thank all who helped me during the field mapping, particularly $\mathrm{Mr}$ Hieronim Wasielewski of Gryżyna Landscape Park and Mr Paweł Krzyżański.

\section{Compliance with ethical standards}

Funding This study was funded by Ministry of Science and Higher Education (Grant Number NN306 035040).

Conflict of interest The authors declare that they have no conflict of interest. This article does not contain any studies with human participants performed by any of the authors. This article does not contain any studies with animals performed by any of the authors. This article does not contain any studies with human participants or animals performed by any of the authors.

Open Access This article is distributed under the terms of the Creative Commons Attribution 4.0 International License (http://crea tivecommons.org/licenses/by/4.0/), which permits unrestricted use, distribution, and reproduction in any medium, provided you give appropriate credit to the original author(s) and the source, provide a link to the Creative Commons license, and indicate if changes were made. 


\section{References}

Abdesselam S, Halitim A, Jan A, Trolard F, Bourrie G (2013) Anthropogenic contamination of groundwater with nitrate in arid region: case study of southern Hodna (Algeria). Environ Earth Sci 70:2129-2141

Aghazadeh N, Mogaddam AA (2011) Investigation of hydrochemical characteristics of groundwater in the Harzandat aquifer, Northwest of Iran. Environ Monit Assess 176:183-195

Amiri V, Sohrabi N, Dadgar MA (2015) Evaluation of groundwater chemistry and its suitability for drinking and agricultural uses in the Lenjanat plain, central Iran. Environ Earth Sci 74:6163-6176

Appelo CAJ, Postma D (1993) Geochemistry, groundwater and pollution. Balkema, Rotterdam

Brzóska J, Karwacka G, Kijowski A, Żynda S (1998) Commentary on the sozological map, scale 1:50000, sheet N-33-139-B, Lubrza

Buszewski B, Kowalkowski T (2003) Poland's environment-past, present and future state of the environment in the Vistula and Odra river basins. Environ Sci Pollut Res 10:343-349

César $\mathrm{E}$, Wildemeersch $\mathrm{S}$, Orban $\mathrm{P}$, Carrière $\mathrm{S}$, Brouyère $\mathrm{S}$, Dassargues A (2014) Simulation of spatial and temporal trends in nitrate concentrations at the regional scale in the Upper Dyle basin, Belgium. Hydrogeol J 22:1087-1100

Chief National Geodesist (2002) Sozological map on a scale 1:50 000, sheet N-33-139-B, Lubrza

Choiński A (1981) Zmienność obiegu wody na Wysoczyźnie Lubuskiej w świetle analizy wybranych elementów środowiska i obliczeń bilansowych, Wydawnictwo PTPNoZ, Zielona Góra

Dragon K (2013) Application of factor analysis to study contamination of a semi-confined aquifer (Wielkopolska Buried Valley aquifer, Poland). J Hydrol 331:272-279

Dragon K, Górski J (2015) Identification of groundwater chemistry origins in a regional aquifer system (Wielkopolska region, Poland). Environ Earth Sci 73:2153-2167

Giridharan L, Venugopal T, Jayaprakash M (2008) Evaluation of the seasonal variation on the geochemical parameters and quality assessment of the groundwater in the proximity of River Cooum, Chennai, India. Environ Monit Assess 143:161-178

Hem JD (1989) Study and interpretation of the chemical characteristics of natural water. US Geol Surv Water-Supply Pap

Idoko OM (2010) Seasonal variation in iron in rural groundwater of Benue State Middle Belt Nigeria. Pak J Nutr 9:892-895

Jeong Ch (2001) Effect of land use and urbanization on hydrochemistry and contamination of groundwater from Taejon area, Korea. J Hydrol 253:194-210

Kabata-Pendias A, Pendias H (1999) Biogeochemia pierwiastków śladowych. PWN, Warszawa

Kazakis N, Vaudouris KS (2015) Groundwater vulnerability and pollution risk assessment of porous aquifers to nitrate: modifying the DRASTIC method using quantitative parameters. J Hydrol 525:13-25

Kehew AE (2001) Applied chemical hydrogeology. Prentice Hall Inc, New Jersey

Kleczkowski AS (1990) Mapa obszarów Głównych Zbiorników Wód Podziemnych (GZWP) w Polsce wymagających szczególnej ochrony. The map of critical protection areas of the major groundwater basins (MGWB) in Poland. Institute of Hydrogeology and Engineering Geology. Academy of Mining and Metallurgy, Cracow

Kumar SK, Rammohan V, Sahayam JD, Jeevanandam M (2009) Assessment of groundwater quality and hydrogeochemistry of Manimuktha river basin, Tamil Nadu, India. Environ Monit Assess 159:341-351

Liana E (2013) Monitoring chemizmu opadów atmosferycznych i ocena depozycji zanieczyszczeń do podłoża. Wyniki badań monitoringowych w województwie lubuskim w 2012 roku. Inspekcja Ochrony Srodowiska, Wrocław

Love D, Hallbauer D, Arnos A, Hranova R (2004) Factor analysis as a tool in groundwater quality management: two southern African case studies. Phys Chem Earth 29:1135-1143

Macioszczyk A, Dobrzyński D (2007) Hydrogeochemia strefy aktywnej wymiany wód podziemnych. PWN, Warszawa

Mazurek M (2008) Factors affecting the chemical composition of groundwater outflows in the southern part of the Parsęta drainage basin (West Pomerania) (Pomorze Zachodnie). Prz Geol 56:131-139 (in Polish with English summary)

Mazurek M, Kruszyk R, Szpikowska G (2014) Transformacja składu chemicznego wód podziemnych w niszach źródliskowych na obszarach młodoglacjalnych (Dorzecze Parsęty). Monografie Komitetu Gospodarki Wodnej PAN 20: 355-369. (in Polish with English summary)

Moosavirad SM, Janardhana MR, Khairy H (2013) Impact of anthropogenic activities on the chemistry and quality of groundwater: a case study from a terrain near Zarand City, Kerman Province, SE Iran. Environ Earth Sci 69:2451-2467

Naseems S, Hamza S, Bashir E (2010) Groundwater geochemistry of Winder agricultural farms, Balochistan, Pakistan and assessment for irrigation water quality. Eur Water 31:21-32

Nowicki Z, Sadurski A (2010) Hydrogeological aspects of Quaternary sediments in Poland. Biul PIG 441:123-129

Ouyang Y, Zhang JE, Parajuli P (2013) Characterization of shallow groundwater quality in the Lower St. Johns River Basin: a case study. Environ Sci Pollut Res 20:8860-8870

Reghunath R, Murthy TR, Raghavan BR (2002) The utility of multivariate statistical techniques in hydrogeochemical studies: an example from Karnataka, India. Water Res 36:2437-2442

Regulation of the Polish Minister of Environment of 09 Sept 2002 (official gazette no. 02.220.1858)

Regulation of the Polish Minister of Health of 29 Mar 2007 (official gazette no. 61, position 417)

Rottray G (2015) Geochemical evolution of groundwater in the Mud Lake area, Eastern Idaho, USA. Environ Earth Sci 73:8251-8269

Szablowska M, Konopczyński W, Demidowicz M, Susek P, Szenfeld M (2013) Stan środowiska w województwie lubuskim w latach 2011-2012. [State of the environment in Lubuskie in 2011-2012] Biblioteka Monitoringu Środowiska, Zielona Góra

Szczucińska AM (2014) Spatial distribution and hydrochemistry of springs and seepage springs in the Lubuska Upland of western Poland. Hydrol Res 45:379-390

Szczucińska AM, WasielewskI H (2013) Seasonal water temperature variability of springs from porous sediments in Gryżynka Valley, western Poland. Quaest Geogr 3:111-117

Szczucińska AM, Siepak M, Marciniak M, Zioła-Frankowska A (2010) Seasonal and spatial changes of metal concentrations in groundwater outflows from porous sediments in the GryżynkaGrabin Tunnel Valley in western Poland. Environ Earth Sci 61:921-930

Tallini M, Parrise B, Petitta M, Spizzico M (2013) Long-term spatiotemporal hydrochemical and ${ }^{222} \mathrm{Rn}$ tracing to investigate groundwater flow and water-rock interaction in the Gran Sasso (central Italy) carbonate aquifer. Hydrogeol J 21:1447-1467

Upadhyaya D, Survaiya MD, Basha S, Mandal SB, Thorat RB, Haldar S, Goel S, Dave H, Baxi K, Trivedi RH (2013) Occurrence and distribution of selected heavy metals and boron in groundwater of the Gulf of Khambhat region, Gujarat, India. Environ Sci Pollut Res 21:2437-2442

Walna B, Siepak M (2012) Heavy metals: their pathway from the ground, groundwater and springs to Lake Góreckie (Poland). Environ Monit Assess 184:3315-3340

WHO (2011) Guidelines for drinking-water quality. World Health Organization, Geneva 
Witczak S, Adamczyk A (1995) Katalog wybranych fizycznych i chemicznych wskaźników zanieczyszczeń wód podziemnych i metod ich oznaczania. Biblioteka Monitoringu Środowiska, PIOŚ, Warszawa

Witczak S, Duda R, Żurek A (2011) Groundwater vulnerability map of Poland. Groundwater vulnerability of shallow aquifers to pollution from land surface 1:500 000. Ministry of the Environment, Krakow

Woś A (1999) Klimat Polski. PWN, Warszawa

Xing L, Guo H, Zhan Y (2013) Groundwater hydrochemical characteristics and processes along flow paths in the North China Plain. J Asian Earth Sci 70-71:250-264 